\title{
DOI:http://dx.doi.org/10.18524/1810-4215.2019.32.182520
}

\section{SOLAR PLASMA DYNAMICS DURING THE FORMATION AND DEVELOPMENT OF ELLERMAN BOMBS PAIR}

\author{
M. N. Pasechnik \\ Main Astronomical Observatory, National Academy of Sciences of Ukraine, \\ Kyiv, Ukraine,rita@mao.kiev.ua
}

ABSTRACT. The results of the specific features study of solar plasma dynamics in different layers of the active region (AR) of NOAA 11024 under the influence arisen and evolving two Ellerman bombs (EB-1 and EB-2) are presented. Spectral data with high spatial and temporal resolution were obtained with the French-Italian THEMIS solar telescope. We used spectra were obtained in the $H_{\alpha}$-line and in the lines forming within a wide range of photospheric heights: FeI $\lambda \lambda 630.15,630.25$, and $630.35 \mathrm{~nm}$ and TiI $\lambda 630.38$ $\mathrm{nm}$. EBs evolved in the region magnetic flux that were emerging at the time. Changes in the velocity and direction of chromospheric and photospheric matter motion in the region of Ellerman bombs and in their immediate vicinity at different stages of EBs evolution were determined and analyzed.

Temporal variations in the line-of-sight velocities (Vlos) of the chromospheric matter at a level of the $H_{\alpha}$ core formation showed two periods in the velocity enhancement, containing several individual peaks. The maximum Vlos was -9 and $8 \mathrm{~km} / \mathrm{s}$ toward and from the observer, respectively. Rapid upward and downward plasma streams (where Vlos reaches -80 and 50 $\mathrm{km} / \mathrm{s}$, respectively) were sometimes observed.

It was found that upflows were predominant at all levels of the AR photosphere. At the same time, Vlos decreased considerably in the region of EBs. Apparently, the small-scale downward flows induced by magnetic reconnections were superimposed onto the largescale upward motion of the new magnetic flux plasma. The line-of-sight velocity in the central part of EB-1 and EB-2 varied from -1 to $0 \mathrm{~km} / \mathrm{s}$ and from -1 to 0.2 $\mathrm{km} / \mathrm{s}$ in the upper photospheric layer and from -1.6 to $-0.2 \mathrm{~km} / \mathrm{s}$ and from -1.1 to $0.25 \mathrm{~km} / \mathrm{s}$ in the lower layer of the photosphere, respectively.

The studied features of temporary changes in the line-of-sight velocities of the chromospheric and photospheric matter during the formation and development of Ellerman bombs indicate that they affect both the photosphere and the lower chromosphere.

Keywords: Ellerman bombs, chromosphere, photosphere, line-of-sight velocities.
АНОТАЦЯ. Представлено результати дослідження особливостей динаміки сонячної плазми в різних шарах активної області NOAA 11024 під впливом двох бомб Еллермана (BE-1 та BE-2), які виникли і розвивалися. Спектральні дані з високою просторовою та часовою роздільною здатністю було отримано за допомогою франко-італійського сонячного телескопа THEMIS. Ми використали спектри, які було отримано в лінї $H_{\alpha}$ та в лініях, що формуються в широкому діапазоні фотосферних висот: FeI $\lambda$ 630.15, 630.25 і 630.35 нм та TiI $\lambda$ 630.38 нм. Бомби Еллермана розвивалися в області магнітного потоку, що виходив в той час. Визначено та проаналізовано зміни швидкості та напрямку руху хромосферної та фотосферної речовини в області бомб Еллермана та їх найближчих околиць на різних стадіях розвитку ВЕ.

Часові зміни променевої швидкості (Vlos) хромосферної речовини на рівні формування ядра лініі $H_{\alpha}$ мали два періоди збільшення швидкості, які складалися 3 декількох окремих піків. Максимальна Vlos становила -9 та 8 км/с у напрямку спостерігача та від нього, відповідно. В деякі моменти спостережень існували потоки плазми вгору та вниз, де Vlos сягала -80 та 50 км/с, відповідно.

Було встановлено, що на всіх рівнях фотосфери в активної області відбувався переважно підйом речовини. $\mathrm{У}$ той же час спостерігалося помітне зменшення Vlos в місцях розташування BE. Ймовірно, дрібномасштабні низхідні потоки, викликані магнітними перез'єднаннями, накладалися на великомасштабний висхідний рух плазми нового магнітного потоку. Променева швидкість в центральній частині BE-1 та BE-2 змінювалася від -1 до $0 \mathrm{~km} / \mathrm{c}$ і від -1 до $0.2 \mathrm{kM} / \mathrm{c}$ у верхньому шарі фотосфери та від -1.6 до -0.2 $\mathrm{kм} / \mathrm{c}$ і від $-1,1$ до $0.25 \mathrm{~km} /$ с у нижньому шарі фотосфери, відповідно. Досліджені особливості часових змін променевих швидкостей хромосферної та фотосферної речовини під час формування та розвитку бомб Еллермана свідчать, що вони 


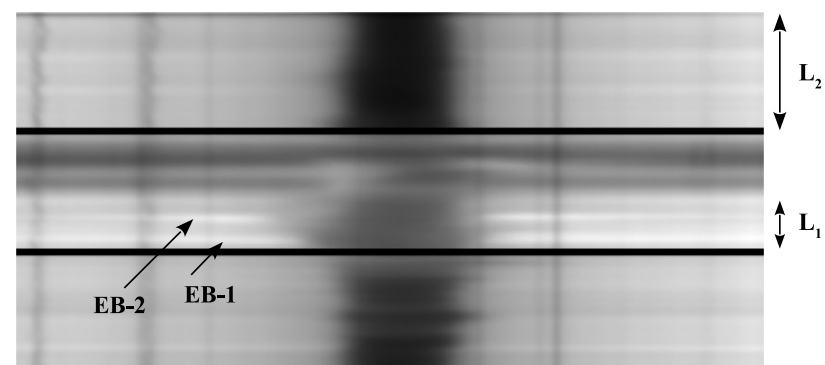

Figure 1: $H_{\alpha}$ spectrum of the AR obtained at 9:42:45 UT. EB-1 and EB-2 are Ellerman bombs, L1 is the analyzed area, and L2 is the AR section lies outside the region of emerging magnetic flux and without active structures.

впливають як на фотосферу, так i на нижню хромосферу.

Ключові слова: бомби Еллермана, хромосфера, фотосфера, променеві швидкості.

\section{Introduction}

Ellerman bombs (EBs), or moustaches, are a part of solar activity. They are short-lived, small-scale bright structures in the solar atmosphere. EBs connected with a rapid local release of energy, magnetic fields, and specific plasma motions (Nelson et al. 2013). Ellerman bombs can affect the complex dynamics of the upper solar atmosphere. They mostly appear in the young developing active regions (ARs) with a complex magnetic structure, in the regions of emerging magnetic fluxes, and in the vicinity of sunspots. Although this interesting phenomenon has been in the focus of many studies, but in which layer of the solar atmosphere magnetic reconnections triggering the formation of EBs occur still remains unclear. Some authors have suggested that Ellerman's bombs are a purely photospheric phenomena (Vissers G. J. M. et al. 2013). It is assumed that the magnetic-field energy in the process of EBs development is spent largely on acceleration of plasma flows. Jets of matter originating at $\mathrm{t}$ he reconnection site form, differently directed motion is observed. The study of matter motion specific features at different levels of the solar atmosphere during EBs development should help determine the height of their formation.

\section{Observational data}

The studied Ellerman bombs (EB-1 and EB-2) emerged and evolved in active region NOAA 11024 (AR). Spectral data with high spatial (below 1 arsec) and temporal (about 3 seconds) resolution were conducted by E.V. Khomenko with the French-Italian
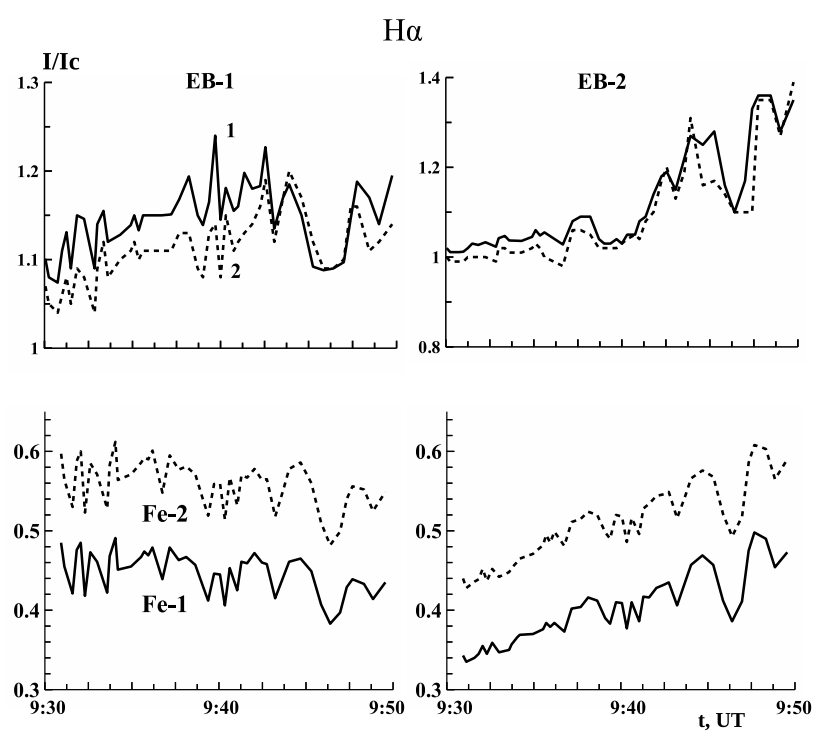

Figure 2: Temporal variations of the emission intensity (I/Ic) in the wings of the $H_{\alpha}$ line at the distances of 0.1 $\mathrm{nm}$ from its center in the long-wavelength (curves 1), short-wavelength (curves 2) wings and also Fe-1, Fe-2 line-center intensity in the spectra of EBs central part.

THEMIS 90-cm vacuum solar telescope on July 4, 2009 (Kondrashova et al., 2013). During 20 minutes, from 09:30 UT to 09:50 UT, 400 spectra of the active region NOAA 11024 were obtained. On the day of our observations AR was at an early stage of evolution, and its activity was quickly growing. In our work we used two spectral regions containing the chromospheric line $H_{\alpha}$ and four Fraunhofer lines forming within a wide range of photospheric heights: two strong neutral iron lines FeI $\lambda \lambda 630.15,630.25 \mathrm{~nm}$ and two weak lines FeI $\lambda 630.35 \mathrm{~nm}$ and TiI $\lambda 630.38 \mathrm{~nm}$. In the paper these lines are denoted as Fe-1, Fe-2, Fe-3 and Ti. It should be noted that two strong and two weak lines forming in upper and lower photospheric layers,respectively.

Figure 1 shows one of the $H_{\alpha}$-spectra AR obtained during our observations. The width of the spectrum range containing the $H_{\alpha}$ line was approximately 0.6 $\mathrm{nm}$. The studied AR site is marked by an arrow L1 and L2 is the AR area without active structures, which was also studied for comparison. Two extended bright narrow emission bands are seen in the wings of the $H_{\alpha}$ line, while a central part of the line is occupied by absorption. These bands are two Ellerman bombs (EB-1 and EB-2) having developed for that time. It is worth noting that the spectra of Ellerman bombs are opposite to the spectra of flares by appearance: in the flares, on the contrary, a strong emission in the center of the $H_{\alpha}$ line and not very extensive and rather weak wings are observed.

EBs evolved in the region of the emerging magnetic 
a

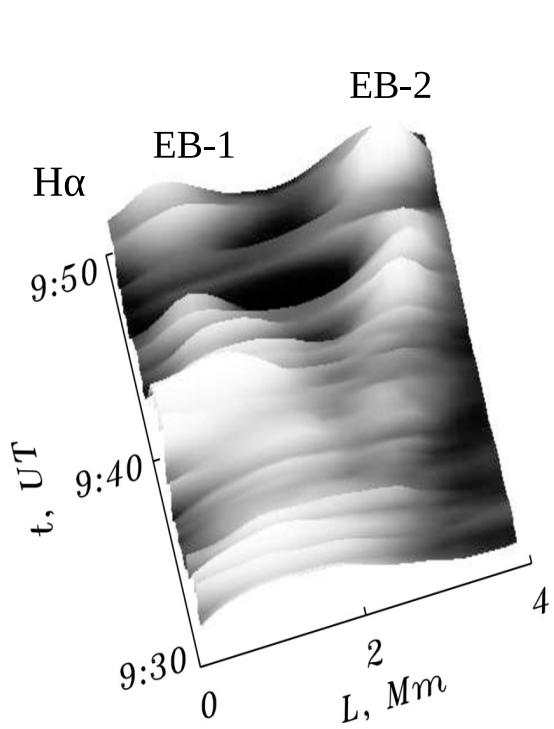

b

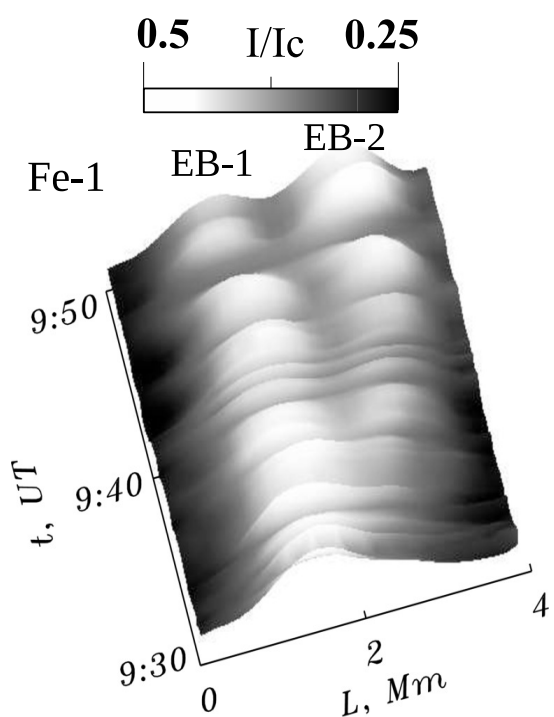

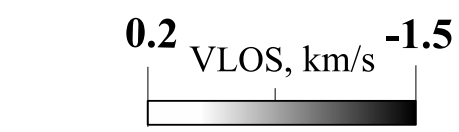

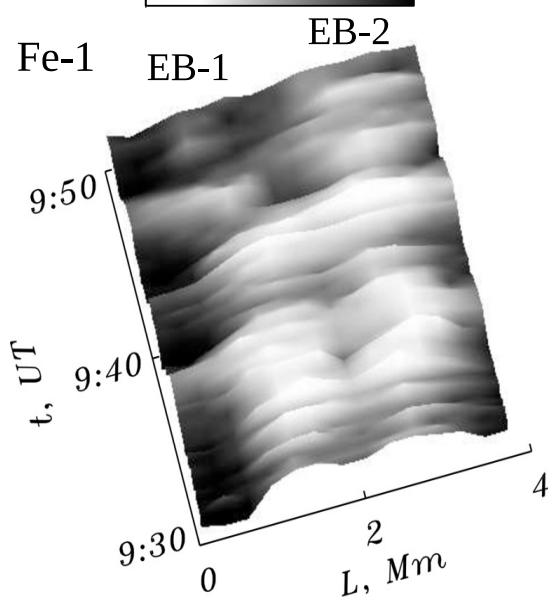

Figure 3: Intensity variations along the spectrograph slit during our observations in the blue wing of the $H_{\alpha}$ line at distance $0.1 \mathrm{~nm}$ from its center (a), in the center of photospheric line FeI-1 (b) and line-of-sight velocity determined from the shifts of the FeI-1 line core (c).

flux (Valori et al., 2012). Interestingly, the beginning of our observations coincided with the initial stage of EB-2 evolution (Pasechnik, 2016).

\section{Temporal EBs evolution}

In our work, we used the Stokes I profiles obtained from the spectra with an interval corresponding to the distance of $160 \mathrm{~km}$ on the solar surface (Pasechnik, 2016). It was found that the profiles of researched lines determined at different stages of EBs evolution were asymmetric with the emission excess in the longwavelength wing (Fig. 2). Figures 2 and 3 a, b show changes in the intensity of the studied lines in the spectra of Ellerman bombs during our observations. It is seen that the brightness of EB-1 gradually decreased while the brightness of EB-2 increased quite sharply.

All the time curves of brightness variation are shaped like a series of peaks (Fig. 2). This indicates a pulsed release of energy.

At all photospheric levels brightness variations were of an oscillatory nature with an interval of 1-5 min (Fig. 2 and Fig 3 b).

An increase in the core intensity of all the studied photospheric lines was correlated spatially with an increase in the wing intensity of the $H_{\alpha}$ line (Fig. 3 a, b).

Within the first 3 min of observations three peaks (with 1-min intervals between them) are seen in all EB-1 brightness curves (Fig. 2). Figure $3 \mathrm{a}, \mathrm{b}$ illustrates that the excitation induced by consecutive magnetic reconnections in the EB-1 region propagated along a magnetic loop and initiated the formation of EB-2, and then the two EBs evolved as a physically connected pair. It should be noted that observations showed that $50 \%$ of Ellerman bombs appear and disappear in pairs and are likely the bases of compact magnetic loops (Zachariadis et al., 1987).

\section{Variations of Chromospheric and Pho-} tospheric Vlos in the studied AR site with evolving EBs

Changes in the velocity and direction of chromospheric and photospheric matter motion in the region of Ellerman bombs and in their immediate vicinity at different stages of EBs evolution were determined and analyzed (Pasechnik, 2019).

Temporal variations in the line-of-sight velocities of the chromospheric material at a level of the $H_{\alpha}$ core formation showed two periods in the velocity enhancement, containing several individual peaks. The maximum Vlos was -9 and $8 \mathrm{~km} / \mathrm{s}$ toward and from the observer, respectively. Figure 5 a shows that the periods of the velocity growth contained three individual peaks.

It was found that upflows were predominant at all levels of the AR photosphere. While noticeable decrease of the line-of-sight velocity magnitudes was observed at the EBs location (Fig. 4). Apparently, the 

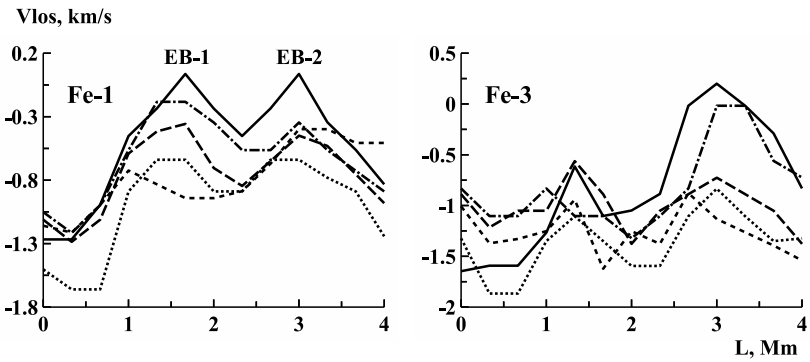

Figure 4: Line-of-sight velocity variations along the spectrograph slit at different moments of observation (Curves 1-5).

small-scale downward flows induced by magnetic reconnections were superimposed onto the large-scale upward motion of plasma of the new magnetic flux. The shape of photospheric lines profiles reinforces this conclusion. The profiles of strong lines that formed in the upper photosphere had a red asymmetry. The profiles of weak lines forming in the lower photosphere had several components in the red wing.

All the Vlos time curves are similar to the brightness variation curves in that they are shaped like a series of peaks (Fig. 2 and Fig. $5 \mathrm{~b}$ ). This suggests that the energy release in Ellerman bombs was associated with successive intermittent magnetic reconnections. Two time periods ( 6 and $4 \mathrm{~min}$ ) comprising several peaks manifested themselves. The velocity of upward motion of photospheric matter decreased considerably within these intervals. The line-of sight velocity in the central part of EB-1 and EB- 2 varied from -1 to $0 \mathrm{~km} / \mathrm{s}$ and from -1 to $0.2 \mathrm{~km} / \mathrm{s}$ in the upper photospheric layer and from -1.6 to $-0.2 \mathrm{~km} / \mathrm{s}$ and from -1.1 to 0.25 $\mathrm{km} / \mathrm{s}$ in the lower layer of the photosphere, respectively (Pasechnik, 2019).

The Ellerman bombs were accompanied by small chromospheric ejections (surges) with upward velocities of about $60 \mathrm{~km} / \mathrm{s}$ and lasting for $0.5-1.5 \mathrm{~min}$ (Pasechnik, 2016).

\section{Conclusions}

Based on the research, it can be concluded that as a result of a new magnetic flux emergence, an EB-1 was formed in the studied of the active region site. In the EB-1 region pulsed energy was released due to successive magnetic reconnections. Excitation propagated from the EB-1 region along the magnetic loop and initiated the formation of EB-2, then they developed as a physically coupled pair (Pasechnik, 2016, 2018).

The studied features of the temporal changes in the line-of-sight velocity of chromospheric and photospheric matter indicate that during the development of EBs, multidirectional movement was observed - in
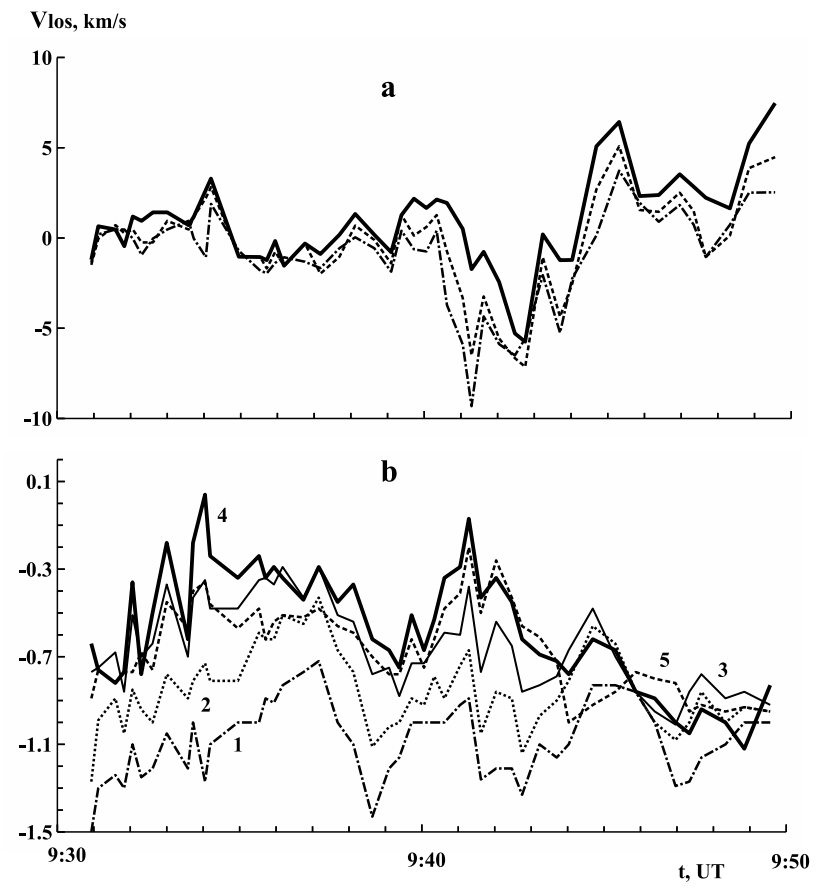

Figure 5: Temporal variations in the chromospheric and photospheric line-of-sight velocity determined from the core line shifts.

the lower chromosphere layer, where the core of the $H_{\alpha}$ line was formed, the matter moved upward, and in the same time downward flows reduced the velocity of ascending plasma at the photosphere level. Such a distribution of velocities could cause magnetic reconnections that occurred in the layer between the upper photosphere and the lower chromosphere. (Pasechnik, 2019). It can be concluded that Ellerman bombs affect both the photosphere and the lower chromosphere.

\section{References}

Kondrashova N. N., Pasechnik M.N., Chornogor S.N. et al.: 2013, Solar. Phys., 284, 499.

Nelson C. J., Doyle J. G., Erdelyi R. et al.: 2013, Solar. Phys., 283, 307.

Pasechnik M.N.: 2016, Kinem. Phys. Cel. Bod., 32, 55.

Pasechnik M.N.: 2016, Kinem. Phys. Cel. Bod., 34, 68.

Pasechnik M.N.: 2016, Kinem. Phys. Cel. Bod., 35, 55.

Valori G., Green L. M., Demouli P. et al.: 2012, Solar. Phys., 278, 73.

Vissers G.J.M., Rouppe van der Voort L.H.M., Rutten R.J.: 2013, ApJ, 774, 32.

Zachariadis Th.G., Alissandrakis C.E., Banos G.: 1987, Solar. Phys., 108, 227. 